\begin{tabular}{l|l|}
\hline $\begin{array}{l}\text { J. To: (Receiving Organization) } \\
\text { Jistribution }\end{array}$ & $\begin{array}{l}\text { 3. From: (Originating Organization) } \\
\text { Fuel Characterization } \\
\text { Project/2T650 }\end{array}$ \\
\hline $\begin{array}{l}\text { 5. Proj./Prog./Dept./Div.: } \\
\text { Spent Nuclear Fuel Project }\end{array}$ & $\begin{array}{l}\text { 6. Design Authority/ Design Agent/Cog. } \\
\text { Engr.: A. Lawrence }\end{array}$ \\
\hline
\end{tabular}

8. originator Remarks:

For approval and information.

11. Receiver Remarks: 11A. Design Baseline Document? [ ] Yes [X] No
4. Related EDT No.:

7. Purchase Order No.:

$N / A$

9. Equip./Component No.: N/A

10. System/Bldg./Facility: $\mathrm{K}$ Basins/100-K

12. Major Assm. Dwg. No.: N/A

13. Permit/Permit Application No.: $N / A$

14. Required Response Date: $N / A$

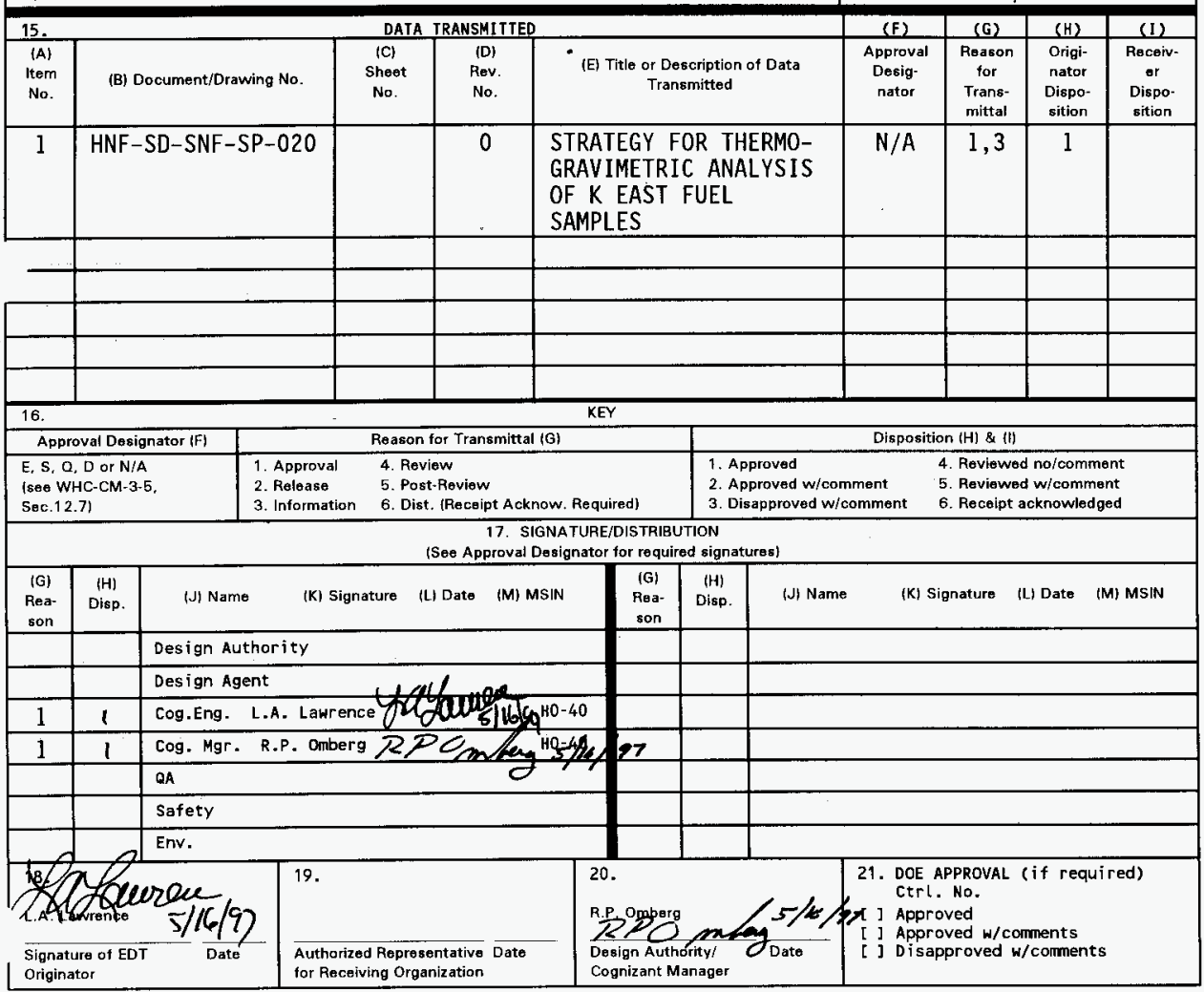




\section{STRATEGY FOR THERMO-GRAVIMETRIC ANALYSIS OF K EAST FUEL SAMPLES}

L. A. Lawrence

DE\&S Hanford, Inc., Richland, WA 99352

U.S. Department of Energy Contract DE-AC06-96RL13200

\begin{tabular}{|c|c|c|}
\hline $\begin{array}{l}\text { DT/ECN: } \\
\text { rg Code: }\end{array}$ & $\begin{array}{l}620790 \\
2 T 650 \\
\text { EW7040000 }\end{array}$ & $\begin{array}{l}\text { UC: } 2070 \\
\text { Charge Code: } \\
\text { Total Pages: }\end{array}$ \\
\hline
\end{tabular}

Key Words: Strategy, Thermo-Gravimetric Analysis Fuel Examinations, 105-K West, Spent Nuclear Fuel

Abstract: A strategy was developed for the Thermo-Gravimetric Analysis (TGA) testing of $K$ East fuel samples for oxidation rate determinations. Tests will first establish if there are any differences for dry air oxidation between the $K$ West and $K$ East fuel. These tests will be followed by moist inert gas oxidation rate measurements. The final series of tests will consider pure water vapor i.e., steam.

TRADEMARK DISCLAIMER. Reference herein to any specific commercial product, process, or service by trade name, trademark, manufacturer, or otherwise, does not necessarily constitute or imply its endorsement, recommendation, or favoring by the United States Government or any agency thereof or its contractors or subcontractors.

Printed in the United States of America. To obtain copies of this document, contact: Document Control Services, P.O. Box 950, Majlstop H6-08, Richland WA 99352, Phone (509) 372-2420;

Fax (509) 376-4989.
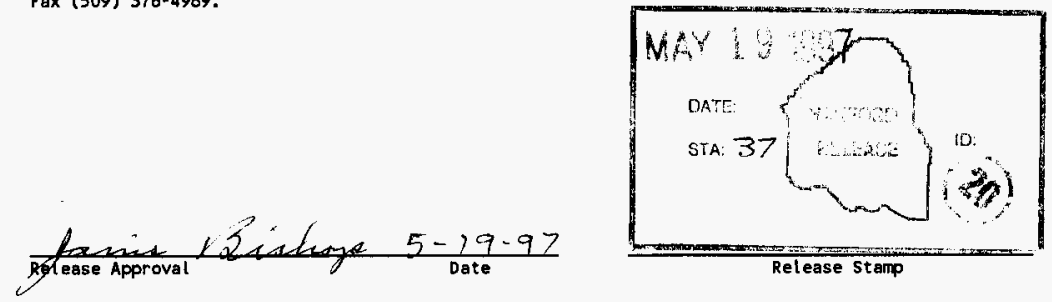

Approved for Public Release 
HNF-SD-SNF-SP-020, Rev. 0

\section{STRATEGY FOR THERMO-GRAVIMETRIC ANALYSIS OF $K$ EAST FUEL SAMPLES}

L. A. Lawrence

Duke Engineering \& Services Hanford, Inc.

May 1997 
Document Title: STRATEGY FOR THERMO-GRAVIMETRIC ANALYSIS OF $K$ EAST FUEL SAMPLES

Prepared by:

Approved by:

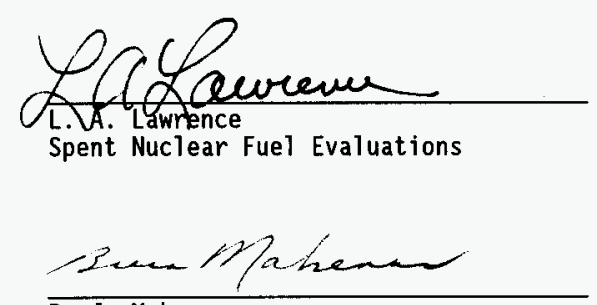

Approved by:

Approved by:

Approved by:

Approved by:
B. J. Makenas

Spent Nuclear Fuel Evaluations

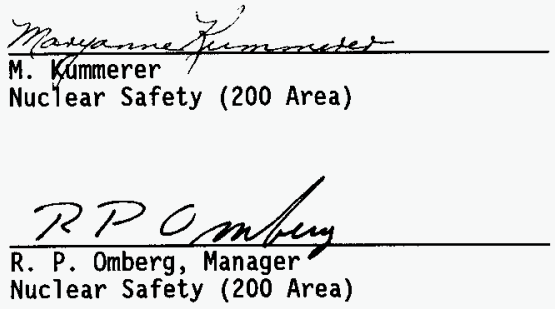

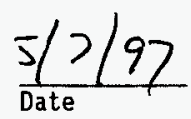

$5 / 7 / 97$

Date

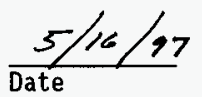

R. P. Omberg, Manager

Characterization Program

$\frac{5-14-97}{\text { Date }}$

S. C. Marschman, Manager

Fuels and Dry Storage

Pacific Northwest National Laboratory

Spent Nuclear Fuels Project
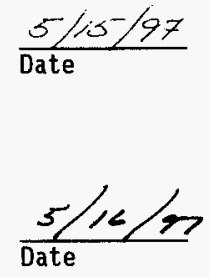
HNF-SD-SNF-SP-020, Rev. 0

This page intentionally left blank. 
HNF-SD-SNF-SP-020, Rev. 0

\section{EXECUTIVE SUMMARY}

A strategy was developed for the Thermo-Gravimetric Analysis (TGA) testing of $K$ East fuel samples for oxidation rate determinations. This strategy supports the preparation of the Safety Analysis Report and process design for the Integrated Process Strategy with special focus on Cold Vacuum Drying and Staging. Tests will first establish if there are any differences for dry air oxidation between the $K$ West and $K$ East fuel. These tests will be followed by moist inert gas oxidation rate measurements. The final series of tests will consider pure water vapor i.e., steam. Detailed Test Instructions will be prepared based on this strategy document and appropriate Letters of Instruction. 
HNF-SD-SNF-SP-020, Rev. 0

This page intentionally left blank. 


\section{HNF-SD-SNF-SP-020, Rev. 0}

\section{CONTENTS}

1.0 INTRODUCTION ....................... . . . 7

2.0 ISSUES FOR K EAST FUEL THERMO-GRAVIMETRIC ANALYSIS TESTING . . . . . 9

3.0 MEASUREMENT STRATEGY . . . . . . . . . . . . . . . 11

3.1 TEST MATRICES . . . . . . . . . . . . . . 11

4.0 REFERENCES . . . . . . . . . . . . . . 17 
HNF-SD-SNF-SP-020, Rev. 0

\section{LIST OF FIGURES}

1. Logic Diagram for Initial Decisions Concerning

Thermo-Gravimetric Analyses Testing . . . . . . . . . . . 12

\section{LIST OF TABLES}

1. Test Matrix for K East Fuel Dry Air 0xidation . . . . . . . . 13

2. Test Matrix for K East Fuel Moist-Inert Gas Mixture Oxidation . . 14

3. Test Matrix for $K$ East Dry Air Oxidation of Samples from Element 2722E.................... 16

4. Test Matrix for K East Fuel Steam Oxidation .......... 16 
HNF-SD-SNF-SP-020, Rev. 0

\section{STRATEGY FOR THERMO-GRAVIMETRIC ANALYSIS OF $K$ EAST FUEL SAMPLES}

\subsection{INTRODUCTION}

This plan establishes the strategy and specific measurements to be conducted for the Thermo-Gravimetric Analysis (TGA) testing of the $K$ East fuel samples for oxidation rate determinations. These examinations will provide essential first time data from the fuel stored in K East to support the preparation of the Safety Analysis Report and process design for the Integrated Process Strategy.

Small samples were removed from the damaged end of two $K$ East fuel elements (i.e., Elements $2722 \mathrm{E}$ and $2540 \mathrm{E}$ ) for the TGA testing (Lawrence 1996a). Thermo-gravimetric analysis testing for chemical reaction rates, hydrogen release, and fuel drying studies were identified in the Data Quality Objectives (DQO) for these $K$ East fuel elements (Lawrence 1996b).

The DQO did not however provide the specific measurements to be conducted to address the current issues related to utilization of oxidation rate data in the process design and safety calculations. This strategy document provides the specific tests to be conducted on the $K$ East fuel samples. This strategy may be modified in the future to better address the performance issues as data are accumulated on the behavior of the $K$ East fuel material. 
HNF-SD-SNF-SP-020, Rev. 0

This page intentionally left blank. 
HNF-SD-SNF-SP-020, Rev. 0

\subsection{ISSUES FOR $K$ EAST FUEL THERMO-GRAVIMETRIC ANALYSIS TESTING}

Oxidation rate measurements of the $K$ West fuel samples have shown the rates in dry air for damaged fuel to be higher than the rate equation obtained from the laboratory measurements of unirradiated uranium (Abrefah 1996). The damaged fuel in the $K$ East Basin is different in appearance from the $K$ West fuel that was stored in closed canisters (Pitner 1995, 1997). These differences in the appearance and extent of damage may lead to differences in the oxidation rate for the damaged fuel. The question is, "Does the $K$ East fuel represent a different population or does the damaged fuel in both basins behave similarly in dry air?"

The second issue relates to the oxidation behavior in atmospheres different from dry air. Laboratory measurements of $K$ West fue 1 showed the moist air oxidation rates to generally agree with the literature based on moist air oxidation of unirradiated uranium (Abrefah 1997). Sample environments in addition to dry and moist air that are of interest to the process and safety calculations include steam, moist inert gas mixtures, hydrogen, and also nitrogen (Lawrence 1997).

Current priorities for the Cold Vacuum Drying (CVD) safety analysis have identified steam and moist inert gas mixtures as the areas of most concern. Steam and liquid water conditions occur during the actual CvD cycles whereas the moist inert gas mixtures occur during CVD, transportation, and staging.

In summary, the following questions were identified for the TGA testing of $K$ East fuel samples.

1. Does the $K$ East damaged fuel represent a different population compared to the $K$ West damaged fuel for oxidation rate behavior?

2. What are the reaction rates for damaged fuel in steam, moist inert gas mixtures, hydrogen, and nitrogen, in addition to dry and moist air?

Secondary questions such as, what is the sample to sample variability in behavior for a given sample or set of test conditions, and what are the effects of differing test conditions such as relative humidity of the gas mixtures, etc., will also be addressed by the measurements outlined in this strategy. 
HNF-SD-SNF-SP-020, Rev. 0

This page intentionally left blank. 
HNF-SD-SNF-SP-020, Rev. 0

\subsection{MEASUREMENT STRATEGY}

The measurement strategy selected was to first compare the measurements for dry air oxidation from $K$ East fuel to those from $K$ West for a limited number of samples. These measurements will be followed by a series of measurements in moist inert gas mixtures. During this time interval the design and equipment procurements and assembly will be completed to upgrade the TGA to handle steam. These two parallel activities ensure that the TGA is being fully utilized to address the identified issues as well as being upgraded to handle steam.

The logic for the initial decisions concerning the TGA testing is summarized in Figure 1. If the dry air oxidation rates of $K$ East fuel samples compare favorably to the measurements of similar samples from $K$ West, then the testing will proceed to the measurements for moist inert gas mixtures and steam. If however, the oxidation rates for $K$ East fuel are different from $K$ West then the question is does $K$ East dry air bound $K$ West experience? If the $K$ East measurements bound $K$ West then the $K$ East measurements can be utilized in the analyses for $K$ West and the measurements will proceed with $K$ East samples in moist inert gas mixtures and steam oxidation. If the measurements do not bound the $K$ West data, that is the $K$ East measurements suggest lower oxidation rates than $K$ West, it will be necessary to revise this strategy and test matrices to expand the measurements for the $K$ West fuel elements removed from the basin during the second fuel examination campaign in $K$ West. $K$ West fuel will be the first material removed from the basins and processed for interim storage. Therefore, a definitive basis of oxidation rate data for $K$ West fuel is necessary to proceed with overall project plans.

\subsection{TEST MATRICES}

The following matrices were established for the testing. The test matrix for dry air oxidation includes samples from elements from both $K$ East and $K$ West (Table 1). The initial test matrix includes four tests with $K$ West fuel samples, i.e., Elements 4366 and 4378, to increase the data points for the temperature range being tested. Discussions concerning the anticipated statistical comparison of the limited $K$ West and $K$ East data suggested that adding three temperatures primarily at temperatures expected in the process would strengthen the statistical analysis. Measurements of samples from the $K$ East Element $2540 E$ will be conducted at the same temperatures as the $K$ West samples i.e., 150 to $350^{\circ} \mathrm{C}$. Specific sample numbers will be established when the sectioning is completed and the samples characterized as to size, surface condition, sample weight, etc. Similar samples will be selected to minimize sample to sample variability in order to focus on establishing the temperature dependence on the oxidation rate.

The test matrix for moist-inert gas mixtures includes temperature, ranging from 100 to $350^{\circ} \mathrm{C}$ (Table 2). Helium-water mixtures at two different partial pressures of water in the system at temperatures are included along with duplicate test samples at the lower temperatures to establish sampleto-sample variability in the material response to the test conditions. These 
Figure 1. Logic Diagram for Initial Decisions

Concerning Thermo-Gravimetric Analyses Testing.

$K$ East fuel dry air oxidation rates are similar to $K$ West

\section{Proceed with}

$K$ East measurements of moist-inert, and steam oxidation

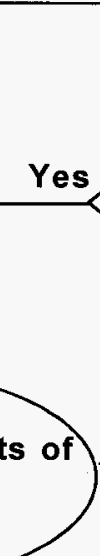

Revise TGA testing

strategy (this document) to utilize $K$ West fuel samples from second shipment 
Table 1. Test Matrix for K East Fuel Dry Air 0xidation.

\begin{tabular}{||c|c|c|c||}
\hline $\begin{array}{c}\text { Test } \\
\text { Number }\end{array}$ & Sample Number & $\begin{array}{c}\text { Sample } \\
\text { Temperature }\left({ }^{\circ} \mathrm{C}\right)\end{array}$ & $\begin{array}{c}\text { Sample } \\
\text { Atmosphere }\end{array}$ \\
\hline 1 & $4366-1^{*}$ & 175 & Dry air \\
\hline 2 & $4366-2$ & 225 & Dry air \\
\hline 3 & $4378-1$ & 225 & Dry a ir \\
\hline 4 & $4378-2$ & 275 & Dry air \\
\hline 5 & $2540 \mathrm{E}-1$ ** & 150 & Dry air \\
\hline 6 & $2540 \mathrm{E}-2$ & 175 & Dry air \\
\hline 7 & $2540 \mathrm{E}-3$ & 200 & Dry a ir \\
\hline 8 & $2540 \mathrm{E}-4$ & 225 & Dry air \\
\hline 9 & $2540 \mathrm{E}-5$ & 250 & Dry air \\
\hline 10 & $2540 \mathrm{E}-6$ & 275 & Dry air \\
\hline 11 & $2540 \mathrm{E}-7$ & 300 & Dry air \\
\hline 12 & $2540 \mathrm{E}-8$ & 350 & Dry air \\
\hline
\end{tabular}

*Specific sample numbers from $K$ West Elements 4366 and 4378 will be established based on the existing sample inventory.

$* *$ Specific sample numbers from Element $2540 \mathrm{E}$ will be established when sectioning is complete and samples are characterized. 
HNF-SD-SNF-SP-020, Rev. 0

Table 2. Test Matrix for $\mathrm{K}$ East Fuel Moist-Inert Gas Mixture 0xidation.

\begin{tabular}{||c|c|c|c||}
\hline $\begin{array}{c}\text { Test } \\
\text { Number }\end{array}$ & Sample Number* & $\begin{array}{c}\text { Sample } \\
\text { Temperature } \\
\left({ }^{\circ} \mathrm{C}\right)\end{array}$ & $\begin{array}{c}\text { Hel ium Water } \\
\text { Mixtures, Partial } \\
\text { Pressure of H } \text { H }^{\text {at }} \\
\text { Temperature (KPa) } * *\end{array}$ \\
\hline 13 & $2540 \mathrm{E}-9$ & 100 & 10 \\
\hline 14 & $2540 \mathrm{E}-10$ & 150 & 10 \\
\hline 15 & $2540 \mathrm{E}-11$ & 200 & 10 \\
\hline 16 & $2540 \mathrm{E}-12$ & 250 & 10 \\
\hline 17 & $2540 \mathrm{E}-13$ & 300 & 10 \\
\hline 18 & $2540 \mathrm{E}-14$ & 350 & 10 \\
\hline 19 & $2540 \mathrm{E}-15$ & 100 & 10 \\
\hline 20 & $2540 \mathrm{E}-16$ & 150 & 10 \\
\hline 21 & $2540 \mathrm{E}-17$ & 200 & 10 \\
\hline 22 & $2540 \mathrm{E}-18$ & 250 & 10 \\
\hline 23 & $2540 \mathrm{E}-19$ & 100 & 40 \\
\hline 24 & $2540 \mathrm{E}-20$ & 150 & 40 \\
\hline 25 & $2540 \mathrm{E}-21$ & 200 & 40 \\
\hline 26 & $2540 \mathrm{E}-22$ & 250 & 40 \\
\hline 27 & $2540 \mathrm{E}-23$ & 300 & 40 \\
\hline 28 & $2540 \mathrm{E}-24$ & 350 & 40 \\
\hline 29 & $2540 \mathrm{E}-25$ & 100 & 40 \\
\hline 30 & $2540 \mathrm{E}-26$ & 150 & 40 \\
\hline 31 & $2540-27$ & 200 & 40 \\
\hline 32 & $2540-28$ & 250 & 40 \\
\hline
\end{tabular}

*Specific sample numbers from Element $2540 E$ will be established when sectioning is complete and samples are characterized.

**At 1 atmosphere pressure. 
test conditions are focused on CVD and staging. When the expected conditions for the Hot Vacuum Drying and long term storage are defined it may be necessary to repeat some of these measurements at different partial pressures or temperatures. A duplication of the tests for different samples were not established for the complete temperature range, i.e., 150 to $350{ }^{\circ} \mathrm{C}$ due to limitations in samples and time to complete the prescribed measurements.

The question of possible differences between elements from $K$ East will be addressed by the following series of measurements (Table 3 ). The $K$ West data for dry and moist air oxidation is primarily from one element i.e., Element 4366. Limited data are available from Element 4378 for $K$ West however, the bulk of the data is from Element 4366. The K East data for the comparison of dry air oxidation is also from one element i.e., Element 2540E. Samples will be available from Element 2722E for a comparison to Element 2540E for possible differences in dry air oxidation from element-to-element. If the comparison of these next few measurements for samples from Element $2722 \mathrm{E}$ shows them to be from the same statistical population as the data for Element $2540 \mathrm{E}$ then samples for Element $2722 \mathrm{E}$ will be utilized for the next series of measurements. If this is not the case and there is a significant difference in behavior between elements from $K$ East it will be necessary to reevaluate this strategy and possibly develop a new one that adequately explores this possible element to element variability in oxidation rate.

The test matrix for steam considers the same temperature range, i.e., 100 to $350^{\circ} \mathrm{C}$ at 1 atmosphere pressure (Table 4 ). Testing includes duplicate samples at each temperature for issues of repeatability and sample-to-sample variations in behavior.

If the system upgrade to handle steam is completed by the end of the dry air oxidation tests, i.e., Run 12, the order of the testing may be revised and the steam oxidation tests conducted before the moist-inert studies (Table 2). This decision will be based on the status of the system upgrade and the current programmatic priorities. Currently, the fuel oxidation in the presence of water vapor, i.e., moist-inert, is the highest priority, however, the issue of $K$ East versus $K$ West fuel behavior must be settled initially.

These test matrices will be modified as necessary when the first series of measurements is complete and the data compared to oxidation rates in dry air for $K$ West fuel samples. If there is a significant difference between $K$ East and $K$ West damaged fuel behavior a revised matrix may be necessary to address these differences. The initial measurements will provide the background and guide for the revision to the testing plans. Similarly if differences occur in the matrices for moist-inert gas mixtures and steam an appropriate change will also be necessary. However, in the absence of any experimental data for these samples or any experience with moist inert gas mixtures or steam, this testing strategy is considered the best approach given the sample and schedule constraints. 
Table 3. Test Matrix for K East Dry Air 0xidation of Samples from Element 2722E.

\begin{tabular}{||c|c|c|l||}
\hline $\begin{array}{c}\text { Test } \\
\text { Number }\end{array}$ & $\begin{array}{c}\text { Sample } \\
\text { Number }\end{array}$ & $\begin{array}{c}\text { Sample } \\
\text { Temperature } \\
\left({ }^{\circ} \mathrm{C}\right)\end{array}$ & $\begin{array}{c}\text { Sample } \\
\text { Atmosphere }\end{array}$ \\
\hline 33 & $2722 \mathrm{E}-1$ & 150 & Dry air \\
\hline 34 & $2722 \mathrm{E}-2$ & 175 & Dry air \\
\hline 35 & $2722 \mathrm{E}-3$ & 200 & Dry air \\
\hline 36 & $2722 \mathrm{E}-4$ & 250 & Dry air \\
\hline 37 & $2722 \mathrm{E}-5$ & 300 & Dry air \\
\hline
\end{tabular}

Table 4. Test Matrix for K East Fuel Steam Oxidation.

\begin{tabular}{|c|c|c|}
\hline $\begin{array}{c}\text { Test } \\
\text { Number }\end{array}$ & $\begin{array}{c}\text { Sample } \\
\text { Number }\end{array}$ & $\begin{array}{c}\text { Sample } \\
\text { Temperature }\left({ }^{\circ} \mathrm{C}\right)\end{array}$ \\
\hline 38 & $2722 \mathrm{E}-4$ & 100 \\
\hline 39 & $2722 \mathrm{E}-5$ & 150 \\
\hline 40 & $2722 \mathrm{E}-6$ & 200 \\
\hline 41 & $2722 \mathrm{E}-7$ & 250 \\
\hline 42 & $2722 \mathrm{E}-8$ & 300 \\
\hline 43 & $2722 \mathrm{E}-9$ & 350 \\
\hline 44 & $2722 \mathrm{E}-10$ & 100 \\
\hline 45 & $2722 \mathrm{E}-11$ & 150 \\
\hline 46 & $2722 \mathrm{E}-12$ & 200 \\
\hline 47 & $2722 \mathrm{E}-13$ & 250 \\
\hline 48 & $2722 \mathrm{E}-14$ & 300 \\
\hline 49 & $2722 \mathrm{E}-15$ & 350 \\
\hline
\end{tabular}




\subsection{REFERENCES}

Abrefah, J., H. C. Buchanan, S. C. Marschman, 1997, Oxidation Rate of $K$ West Spent Nuclear Fuel in Moist Air, SNF CT97:022, Pacific Northwest National Laboratory, Richland, Washington.

Abrefah, J., 1996, H. C. Buchanan, S. C. Marschman, 1996, Oxidation Kinetics of $K$ West Spent Nuclear Fuel in Dry Air, SNF CT97:004, Pacific Northwest National Laboratory, Richland, Washington.

Lawrence, L. A., 1997, Internal Memo to R. P. Omberg and J. A. Swenson, "Notes from Discussions with Marty Plys, Marv Thurgood, and Maryanne Kummerer on Thermo-Gravimetric Analysis Testing, "Duke Engineering \& Services Hanford, Inc., Richland, Washington.

Lawrence, L. A., 1996a, Strategy for Examination of the Initial Nine $K$ East Basin Fuel Elements, WHC-SD-SNF-SP-014, Rev. 0, Westinghouse Hanford Company, Richland, Washington.

Lawrence, L. A., 1996b, Data Quality Objectives for the $K$ East Fuel Examinations, WHC-SD-SNF-DQ0-009, Rev. 0, Westinghouse Hanford Company, Richland, Washington.

Pitner, A. L., 1997a, Visual Examinations of $K$ West Fuel Elements, HNF-SD-SNF-TI-046, Rev. 0, Duke Engineering \& Services Hanford, Inc., Richland, Washington.

Pitner, A. L., 1995, K East Basin Underwater Visual Fuel Survey, WHC-SD-SNF-TI-012, Rev. O, Westinghouse Hanford Company, Richland, Washington. 


\begin{tabular}{|c|c|c|c|c|c|}
\hline \multicolumn{6}{|c|}{ DISTRIBUTION SHEET } \\
\hline \multirow{2}{*}{$\begin{array}{l}\text { To } \\
\text { Distribution }\end{array}$} & \multirow{2}{*}{\multicolumn{3}{|c|}{$\begin{array}{l}\text { From } \\
\text { Fuel Characterization } \\
\text { Project/2T650 } \\
\end{array}$}} & \multicolumn{2}{|l|}{ Page 1 of 3} \\
\hline & & & & \multicolumn{2}{|c|}{ Date $05 / 16 / 97$} \\
\hline \multicolumn{4}{|c|}{ Project Title/Work Order } & \multicolumn{2}{|c|}{ EDT No. 620790} \\
\hline \multicolumn{4}{|c|}{$\begin{array}{l}\text { Spent Nuclear Fuel Project/Stratgey for Thermo-Gravimetric } \\
\text { Analys is of K East Fuel Samples }\end{array}$} & \multicolumn{2}{|l|}{ ECN No. } \\
\hline Name & MSIN & $\begin{array}{l}\text { Text } \\
\text { With All } \\
\text { Attach. }\end{array}$ & Text Only & $\begin{array}{l}\text { Attach./ } \\
\text { Appendix } \\
\text { Only }\end{array}$ & $\begin{array}{l}\text { EDT/ECN } \\
\text { Only }\end{array}$ \\
\hline
\end{tabular}

U.S. Department of Energy, Richland Operations Office

P. G. Loscoe

E. D. Sellers

J. Shuen

G. D. Trenchard S7-41 $\quad x$ S7-41 $\quad x$ S7-41 $\quad x$ S7-41 $x$

Washington State Department of Ecology Post office Box 47600

Olympia, Washington 98504-7600

D. Silver

$x$

Washington State Department of Health Airdustrial Park

Building 5, MaiT Stop LE-13

OTympia, Washington 98504-0095

A. W. Conk 1 in

$x$

Fluor Danie] Northwest

L. J. Garvin

M. Kummerer

D. A. Smith

R3-15

A3-34

R3-15

$x$

$x$

ICF Kaiser

G. Baston

R. P. Denise

R3-82 $\quad X$

R3-82 $X$

Pacific Northwest National Laboratory

J. Abrefah

P7-27

P7-27

K7-94

$x$
$x$
$x$

S. M. Short

SGN Eurisys Services Corp.

A. L. Pajunen

R3-86

$x$ 


\section{DISTRIBUTION SHEET}

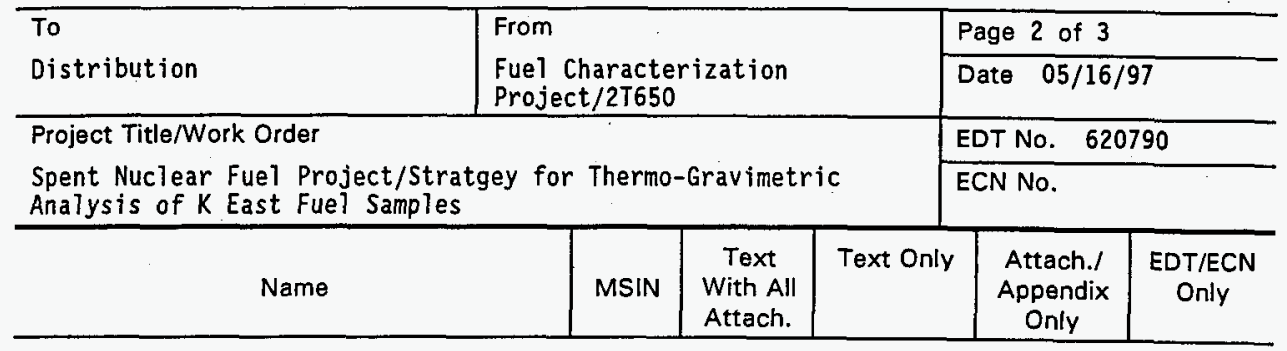

DE\&S Hanford; Inc.

C. J. Alderman

R. B. Baker

A. E. Bridges

B. S. Carlisle

S. A. Chastain

R. G. Cowan

D. R. Duncan

J. R. Frederickson

L. H. Goldmann

S. L. Hecht

F. G. Hudson

A. T. Kee

L. A. Lawrence

P. G. LeRoy

B. J. Makenas

R. P. Omberg

A. L. Pitner

R. W. Rasmussen

E. J. Shen

D. W. Smith

J. A. Swenson

C. A. Thompson

D. J. Trimble

Central Files
D. W. Bergmann

$\begin{array}{ll}X 3-85 & X \\ H 0-40 & X \\ X 3-79 & X \\ H 0-40 & X \\ X 3-75 & X \\ H 0-40 & X \\ \text { R3-86 } & X \\ \text { R3-86 } & X \\ \text { R3-85 } & X \\ \text { R3-86 } & X \\ H 0-40 & X \\ \text { R3-11 } & X \\ \text { R3-86 } & X \\ H 0-40 & X \\ \text { R3-15 } & X \\ H 0-40 & X \\ H 0-40 & X \\ H 0-40 & X \\ \text { R3-86 } & X \\ X 3-75 & X \\ \text { R3-15 } & X \\ \text { R3-11 } & X \\ \text { R3-85 } & X \\ H 0-40 & X \\ \text { A3-88 } & X\end{array}$

Fluor Daniel Hanford, Inc.

E. W. Gerber

R3-11 X

Lockheed Mart in Hanford Corp.

J. J. Irwin
HO-34 X 


\section{DISTRIBUTION SHEET}

\begin{tabular}{|c|c|c|c|c|c|}
\hline \multirow{2}{*}{$\begin{array}{l}\text { To } \\
\text { Distribution }\end{array}$} & \multirow{2}{*}{\multicolumn{3}{|c|}{$\begin{array}{l}\text { From } \\
\text { Fuel Characterization } \\
\text { Project } / 2 T 650\end{array}$}} & \multicolumn{2}{|l|}{ Page 3 of 3} \\
\hline & & & & \multicolumn{2}{|c|}{ Date $05 / 16 / 97$} \\
\hline \multicolumn{4}{|l|}{ Project Title/Work Order } & \multicolumn{2}{|c|}{ EDT No. 620790} \\
\hline \multicolumn{4}{|c|}{$\begin{array}{l}\text { Spent Nuclear Fuel Project/Stratgey for Thermo-Gravimetric } \\
\text { Analys is of } K \text { East Fuel Samples }\end{array}$} & \multicolumn{2}{|l|}{ ECN No. } \\
\hline Name & MSIN & $\begin{array}{l}\text { Text } \\
\text { With All } \\
\text { Attach. }\end{array}$ & Text Only & $\begin{array}{l}\text { Attach./ } \\
\text { Appendix } \\
\text { Only }\end{array}$ & $\begin{array}{l}\text { EDT/ECN } \\
\text { Only }\end{array}$ \\
\hline
\end{tabular}

Numatec Hanford Corporation

G. P. Chevrier

F. W. Bradshaw

J. E. Filip

T. A. Flament

C. R. Miska
R3-86

R3-85

R3-85

K9-46

R3-86
$X$
$X$
$X$
$X$
$X$ 